\title{
Low-oxygen-induced Poststorage Suppression of Bell Pepper Fruit Respiration and Mitochondrial Oxidative Activity
}

\author{
A.S.A. Rahman', D.J. Huber ${ }^{2}$, and J.K. Brecht \\ Horticultural Sciences Department, P.O. Box 110690, Fifield Hall, University of Florida, Gainesville, \\ FL 32611-0690
}

Additional index words. Jupiter, controlled atmosphere

\begin{abstract}
Bell pepper (Capsicum annum var. Jupiter) fruit were exposed to $1.5 \% \mathrm{O}_{2}$ for 1 to 5 days at $20 \mathrm{C}$ to examine whether the low- $\mathrm{O}_{2}$-induced poststorage respiratory suppression (PRS) in whole fruit could be due to limitations in mitochondrial oxidative capacity. Mitochondrial oxidative capacity was not affected after storing bell peppers for 1 day in $1.5 \% \mathrm{O}_{2}$. Extending the storage period from 1 to 5 days in $1.5 \%$, resulted in PRS of $\mathrm{CO}_{2}$ production for about 55 hours after transfer to air, and a marked reduction in the oxidative capacity of isolated mitochondria. Mitochondrial activity was suppressed for 10 hours after transfer to air but, within 24 hours, bad recovered to values comparable to those of mitochondria from fruit stored continuously in air. Storing bell peppers in $1.5 \% \mathrm{O}_{2}$ for 5 days resulted in a reduction in the respiratory control (RC), while ADP/O ratios were not affected. The reduction was temporary since the $\mathrm{RC}$ attained normal activity after returning bell peppers to air. Cyanide-sensitive cytochrome and $\mathrm{CN}$-insensitive pathways were suppressed after storing fruit in $1.5 \% \mathrm{O}_{2}$ for 5 days. After returning fruit from a low- $\mathrm{O}_{2}$ atmosphere to air, the alternative pathway recovered at a greater rate than the cytochrome pathway.
\end{abstract}

Maintaining low respiration during fruit and vegetable storage is important in delaying senescence and avoiding rapid quality deterioration. Controlled-atmosphere or modified-atmosphere storage with low $\mathrm{O}_{2}$, elevated $\mathrm{CO}_{2}$, or both, has successfully reduced respiration and other associated metabolic processes (Kader, 1986).

Our previous studies have shown that whole bell peppers stored in $1.5 \% \mathrm{O}_{2}$ for 1 day at $20 \mathrm{C}$ exhibited suppressed respiration rates that persisted for at least $24 \mathrm{~h}$ after transfer from a low- $\mathrm{O}_{2}$ environment to a normal atmosphere (Rahman et al., 1993). The poststorage respiratory suppression (PRS) was extended to at least $48 \mathrm{~h}$ as the storage period under low $\mathrm{O}_{2}$ was extended from 1 to 3 days. Although whole fruit respiration was continuously suppressed following storage in $1.5 \% \mathrm{O}_{2}$ for 1 day, the inhibition was not reflected in the capacity of isolated mitochondria to oxidize succinate (Rahman et al., 1993).

The central reactions of respiration occur in mitochondria, where several enzymes are involved in transferring electrons from organic molecules to oxygen (Goodwin and Mercer, 1988). Depending on $\mathrm{O}_{2}$ concentration and exposure duration, enzyme activity could be affected by storage under a low- $\mathrm{O}_{2}$ environment. The presence of PRS in bell peppers previously exposed to low $\mathrm{O}_{2}$ could be due to direct or indirect effects on the mitochondrial oxidative capacity. As indicated by Kader (1986), $\mathrm{O}_{2}$ concentrations below $0.02 \%$ restrict the activity of cytochrome oxidase.

Studies have shown that the alternative respiratory pathway $\left(\mathrm{V}_{\text {att }}\right)$ is induced on exposing plant tissues to adverse environmental conditions. Examples include chill-stressed potato leaves (Ordentlich et al., 1991), postchilled tomatoes (De Virville et al., 1987), and aged and $\mathrm{C}_{2} \mathrm{H}_{4}$-treated potato slices (Mikitzel and Knowles, 1990). The Objectives of this study were to 1) determine

Received for publication 31 Mar. 1995. Accepted for publication 26 June 1995. Journal article no. R-04557 of the Florida Agricultural Experiment Station. The cost of publishing this paper was defrayed in part by the payment of page charges. Under postal regulations, this paper therefore must be hereby marked advertisement solely to indicate this fact.

'Present address: Malaysian Agricultural Research and Development Institute (MARDI), Malaysia.

${ }^{2}$ To whom reprint requests should be addressed. whether the occurrence of PRS in bell peppers exposed to low $\mathrm{O}_{2}$ is due to impairment in the mitochondrial oxidative and phosphorylative capacities and 2) examine mitochondrial respiratory components of bell peppers exposed to low $\mathrm{O}_{2}$.

\section{Materials and Methods}

Plant material. Bell peppers were hand-harvested, cleaned, and selected for uniformity of size and shape and freedom from defects. The fruit were wiped with paper towels moistened with $0.25 \%$ (v/v) sodium hypochlorite, rinsed with deionized water, and dried. Individual fruit (average weight of $170 \mathrm{~g}$ ) were placed into 1.7-liter glass jars and kept in a 20C room for $24 \mathrm{~h}$ to allow handling-induced respiration to subside. Fruit samples having uniform $\mathrm{CO}_{2}$ production rates of about $25 \pm 2.5 \mathrm{ml} \cdot \mathrm{kg}^{-1} \cdot \mathrm{h}^{-1}$ were selected for the experiments.

Gas treatments. Fruit were sealed in 9.5-liter glass jars and exposed to $1.5 \% \mathrm{O}_{2}$ in $\mathrm{N}_{2}$ or air for 5 days at 20C. The control consisted of fruit exposed to air. The humidified gas mixtures were introduced by means of a continuous flow-through system with a flow rate of $415 \mathrm{ml} \cdot \mathrm{min}^{-1}$ to maintain $\mathrm{CO}_{2}$ levels below $0.3 \%$.

Gas measurement. Bell pepper $\mathrm{CO}_{2}$ production, as described by Rahman et al. (1993), was determined at intervals after transferring fruit from low- $\mathrm{O}_{2}$ atmosphere to air

Determination of mitochondrial activity. After treatment in $1.5 \% 0$, or air for 1 or 5 days, fruit were transferred to air and ventilated with humidified air at 20C. Mitochondria were isolated and purified from bell peppers as described in detail in Rahman et al. (1993). Respiratory control (RC) and ADP/O ratios were calculated according to the method of Estabrook (1967).

Oxidative capacity with succinate as the substrate was measured using mitochondria prepared from fruit after transfer from low $\mathrm{O}_{2}$ to air and again after $24 \mathrm{~h}$ in air. In another experiment, mitochondria were prepared from fruit after $10 \mathrm{~h}$ in air after storing bell peppers for 5 days in $1.5 \% 0$,

Determination of mitochondrial respiratory components, Total oxidative activity ( $\mathrm{V}_{\text {) }}$ of purified mitochondria was measured using an oxygen electrode (model 53; Yellow Springs Instruments 
Co:, Yellow Springs, Ohio) standardized against air-saturated deionized water. The capacity of the alternate pathway $\left(\mathrm{V}_{\text {att }}\right)$ was determined by measuring the rate of $\mathrm{O}_{2}$ uptake in the presence of $1 \mathrm{~mm} \mathrm{KCN}$ and that of the cytochrome pathway $\left(\mathrm{V}_{\text {att }}\right)$ in the presence of $10 \mathrm{~mm}$ SHAM. Residual respiration $\left(\mathrm{V}_{\text {atl }}\right)$ was estimated in the presence of $\mathrm{KCN}$ and SHAM. Oxygen consumption rate was expressed as $\mathrm{nmol} \mathrm{O}_{2} / \mathrm{mg}$ mitochondrial protein per min. Protein in the mitochondrial preparations was determined using bicinchoninic acid (Smith et al., 1985).

\section{Results}

Effect of low $\mathrm{O}_{2}$ on $\mathrm{CO}_{2}$ production rate of intact bell peppers. Bell peppers stored for 5 days in $1.5 \% \quad \mathrm{O}_{2}$ had suppressed $\mathrm{CO}_{2}$ production rate of about $75 \% 2 \mathrm{~h}$ after transferring fruit to air compared to the continuously air-stored fruit (Fig. 1). The $\mathrm{CO}_{2}$ production rate remained suppressed for $60 \mathrm{~h}$ after transfer to air, during which time $\mathrm{CO}_{2}$ production recovered gradually to values comparable to fruit maintained continuously in air. The $\mathrm{CO}_{2}$ production rate of fruit stored continuously in air decreased gradually during the experiment (Fig. 1).

Effect of low $\mathrm{O}_{2}$ on mitochondrial activity. Mitochondria were isolated from fruit stored in $1.5 \% \mathrm{O}_{2}$ for 1 or 5 days to determine whether the low- $\mathrm{O}_{2}$ induced PRS could be explained by limitations in mitochondrial oxidative capacity. The total $\mathrm{O}_{2}$ uptake capacity $\left(\mathrm{V}_{\mathrm{T}}\right)$ of mitochondria isolated from fruit stored in $1.5 \% 0$, for 1 day was similar to that of mitochondria isolated from fruit stored continu-

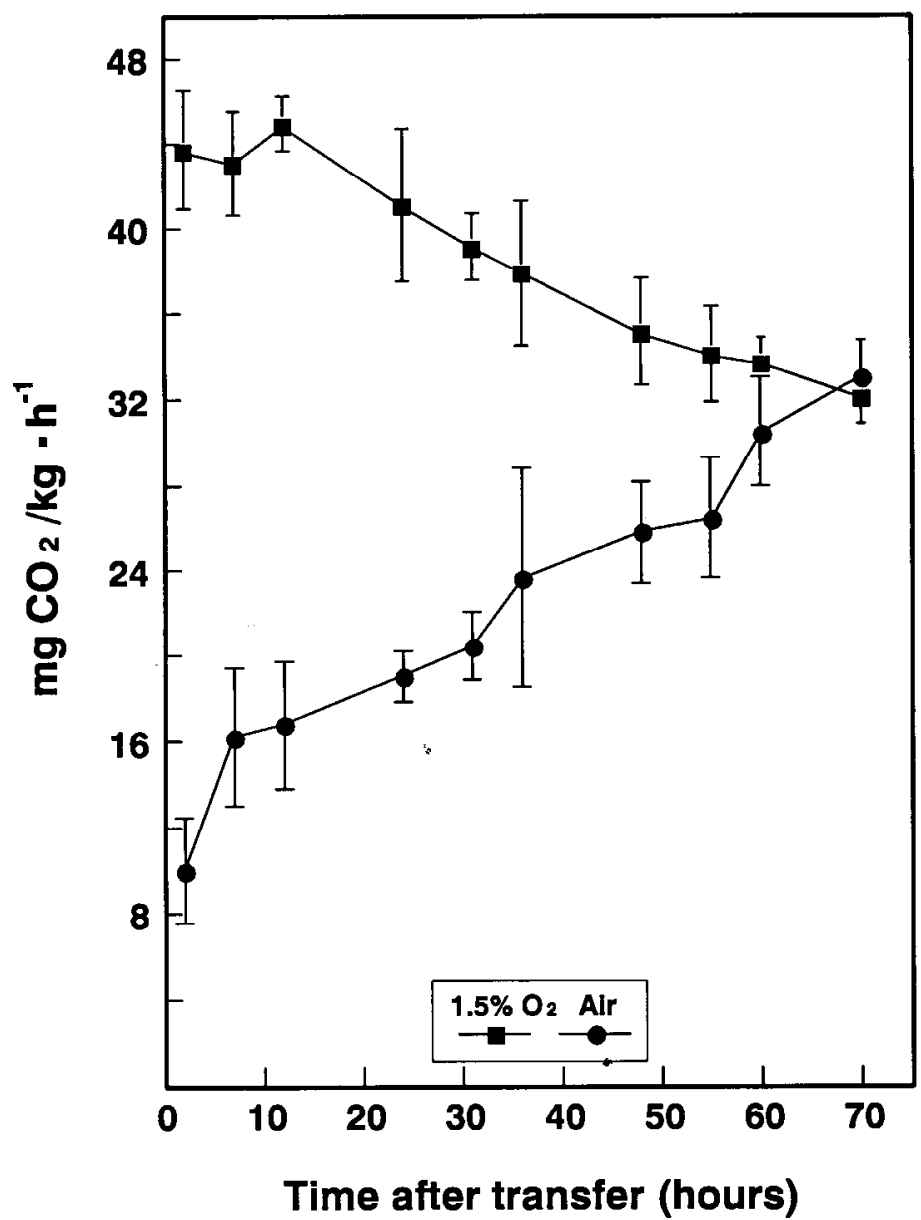

Fig. 1. Carbon dioxide production rates of bell peppers in air following storage in $1.5 \% \mathrm{O}_{2}$ for 5 days ( ), and air-stored fruit $(\mathbf{0})$. Vertical lines represent SD of the mean. ously in air (Fig. 2). Twenty-four hours after transferring fruit from low $\mathrm{O}_{2}$ to air, mitochondrial $\mathrm{O}_{2}$ uptake was similar to that of mitochondria obtained from fruit stored in air for 2 days (Fig. 2). These findings confirm our earlier analyses of mitochondrial activity after a short ( 1 day) exposure to $1.5 \% \mathrm{O}_{2}$ (Rahman et al., 1993).

Bell peppers were stored for 5 days in $1.5 \% \mathrm{O}_{2}$ to determine the effect of extending the storage period on the total oxidative capacity of isolated mitochondria. After removing fruit from 1.5\% $\mathrm{O}_{2}$ storage for 5 days, the oxidative capacity of bell pepper mitochondria, presented here as the maximum rate of state 3 oxidation, was reduced by about $75 \%$ compared to that of mitochondria from air-stored fruit (Table 1). Mitochondria prepared from low $\mathrm{O}_{2}$-treated fruit 1 day after transfer to air exhibited oxidative capacities similar to those of mitochondria derived from fruit stored continuously in air. In an experiment using fruit from a different harvest, mitochondrial oxidative capacity was reduced by about $65 \%$ after storing bell peppers in $1.5 \% \quad \mathrm{O}_{2}$ for 5 days (Table 2). The oxidative capacity of mitochondria exhibited some recovery after transferring fruit to air for $10 \mathrm{~h}$; however, oxidative capacity was still nearly $40 \%$ lower than that of mitochondria from air-stored fruit. These experiments indicate that, while the oxidative capacity of mitochondria from low $-\mathrm{O}_{2}$ stored bell peppers recovers to values comparable to those of air-stored fruit (Tables 1 and 2), the suppression is not rectified immediately upon returning fruit to normal atmosphere but is still apparent $10 \mathrm{~h}$ after removing fruit from the low- $\mathrm{O}_{2}$ environment (Table 2). Although the oxidative competency of mitochondria varied between experi-

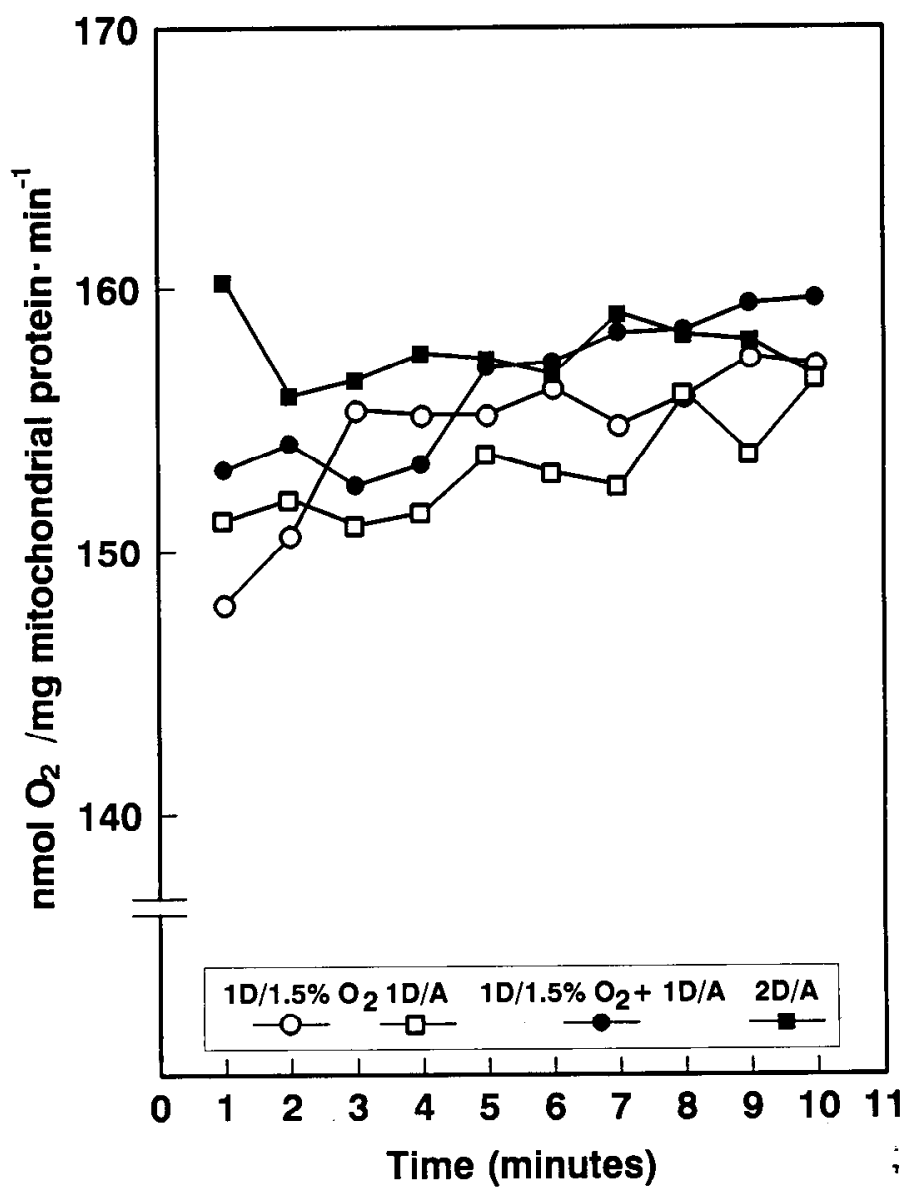

Fig. 2. Oxygen uptake capacity of mitocbondria isolated from bell peppers stored for 1 day in $1.5 \% \mathrm{O}_{2}(\bigcirc), 1$ day in air $(\square), 1$ day in $1.5 \% \mathrm{O}_{2}$ plus 1 day in air $(\bullet)$, and 2 days in air ( $\mathbf{\square})$. 
ments (compare Tables 1 and 2), the relative effects of the different storage conditions were quite consistent.

$R C$ values and $A D P / O$ ratios of mitochondria from stored fruit. Respiratory control and ADP/Oratios were examined to determine whether the mitochondrial oxidative and phosphorylative properties were affected by prior storage of bell peppers under low $\mathrm{O}_{2}$ (Table 3). As shown in Table 3, the $\mathrm{RC}$ and $\mathrm{ADP} / \mathrm{O}$ ratios of mitochondria from fruit stored in $1.5 \% \mathrm{O}_{2}$ for 1 day or 1 day after transfer from $1.5 \% \mathrm{O}_{2}$ to air were not significantly different from those obtained with mitochondria from fruit stored continuously in air. In contrast, the RC values of mitochondria from bell peppers stored for 5 days in $1.5 \% \mathrm{O}_{2}$ were significantly $(P \leq 0.01)$ lower than those stored continuously in air (Table 4). There was a significant recovery in $\mathrm{RC}$ values noted in mitochondria from fruit stored for 5 days in low $\mathrm{O}_{2}$ followed by $10 \mathrm{~h}$ in air (Table 4); however, values remained significantly $(\mathrm{P} \leq 0.01)$ lower than those of the air-stored fruit. The recovery trend for $\mathrm{RC}$ values parallels that noted for total oxidative capacity. The ADP/O ratios of

Table 1. Maximum sustained state $3 \mathrm{O}_{2}$ consumption in mitochondria isolated from bell pepper fruit following storage under low oxygen or in air.

\begin{tabular}{lc}
\hline Treatment & nmol $\mathrm{O}_{2} / \mathrm{mg}$ mitochondrial protein per $\mathrm{min}^{2}$ \\
\hline 5 Days/air & 142.3 \\
5 Days/1.5\% $\mathrm{O}_{2}+1$ Day/air & 122.0 \\
6 Days/air & 123.7 \\
\hline
\end{tabular}

${ }^{\mathrm{z}}$ Data the means of two separate determinations.

Table 2. Maximum sustained state $3 \mathrm{O}_{2}$ consumption in mitochondria isolated from bell pepper fruit following storage under low $\mathrm{O}_{2}$ or in air.

\begin{tabular}{lc}
\hline \hline Treatment & $\mathrm{nmol} \mathrm{O}_{2} / \mathrm{mg}$ mitochondrial protein per $\min ^{2}$ \\
\hline 5 Days $/ 1.5 \% \mathrm{O}_{2}$ & 67.4 \\
5 Days/air & 188.7 \\
5 Days/1.5\% $\mathrm{O}_{2}+10 \mathrm{~h}$ air & 90.3 \\
5.4 Days/air & 143.0
\end{tabular}

${ }^{\mathrm{Z}}$ Data the means of two separate determinations

Table 3. Respiratory control (RC) and ADP/O ratios of mitochondria isolated from fruit stored in $1.5 \% \mathrm{O}_{2}$ for 1 day and 1 day after transfer to air, and air-stored fruit.

\begin{tabular}{llc}
\hline \hline Treatment & $\mathrm{RC}$ & $\mathrm{ADP} / \mathrm{O}$ \\
\hline $1 \mathrm{Day} / 1.5 \% \mathrm{O}_{2}$ & $2.15 \mathrm{a}^{z}$ & $1.99 \mathrm{a}$ \\
$1 \mathrm{Day} / \mathrm{air}$ & $2.17 \mathrm{a}$ & $2.00 \mathrm{a}$ \\
1 Day/1.5\% $\mathrm{O}_{2}+1 \mathrm{D} / \mathrm{air}$ & $2.50 \mathrm{a}$ & $2.01 \mathrm{a}$ \\
2 Days/air & $2.43 \mathrm{a}$ & $2.03 \mathrm{a}$
\end{tabular}

${ }^{2}$ Data are means of three replications. Means followed by the same letter within a column are not significantly different at 0.05 level by DMRT.

Table 4. Respiratory control (RC) and ADP/O ratios of mitochondria isolated from fruit stored in $1.5 \% \mathrm{O}_{2}$ for 5 days and $10 \mathrm{~h}$ after transfer to air, and air-stored fruit."

\begin{tabular}{llc}
\hline \hline Treatment & $\mathrm{RC}$ & ADP/O \\
\hline 5 Days $/ 1.5 \% \mathrm{O}_{2}$ & $1.42 \mathrm{c}^{\mathrm{z}}$ & $1.81 \mathrm{a}$ \\
5 Days/air & $2.68 \mathrm{a}$ & $1.86 \mathrm{a}$ \\
5 Days $/ 1.5 \% \mathrm{O}_{2}+10 \mathrm{~h} /$ air & $2.37 \mathrm{~b}$ & $1.83 \mathrm{a}$ \\
5.4 Days/air $(130 \mathrm{~h})$ & $2.69 \mathrm{a}$ & $1.85 \mathrm{a}$
\end{tabular}

${ }^{\mathrm{x}}$ Data are the means of three replications. Means followed by the same letter within a column are not significantly different at 0.01 level by DMRT. mitochondria from fruit stored in $1.5 \% \mathrm{O}_{2}$ or $10 \mathrm{~h}$ after transfer to air were not significantly different from those of mitochondria from fruit stored continuously in air (Table 4).

Changes in mitochondrial respiratory components. Experiments were performed to determine the influence of low- $\mathrm{O}_{2}$ storage on the various oxidative components of mitochondria. Total respiratory activity $\left(\mathrm{V}_{\mathrm{T}}\right)$ of mitochondria from fruit stored in $1.5 \% \mathrm{O}_{2}$ for 1 day was not significantly different from that of mitochondria isolated from air-stored fruit (Table 5). Twenty four hours after transfer to air, $\mathrm{V}_{\mathrm{T}}$ increased slightly but was not significantly different from the $\mathrm{V}_{\mathrm{T}}$ of mitochondria isolated from fruit stored in $1.5 \% \mathrm{O}_{2}$ for 1 day, but was higher than VT of mitochondria from air-stored fruit. The capacities of $\mathrm{V}_{\text {cyt }}$ and $\mathrm{V}_{\text {alt }}$ were significantly higher $(P \leq 0.01)$ after storing fruit for 1 day $m$ $1.5 \% \mathrm{O}_{2}$ compared to those of mitochondria from air-stored fruit (Table 5). One day after transferring fruit from low- $\mathrm{O}_{2}$ to air, $\mathrm{V}_{\text {att }}$ wassignificantly $(P \leq 0.01)$ higher $(17 \%)$ than the $\mathrm{V}_{\text {att }}$ of mitochondria from fruit stored in $1.5 \% \mathrm{O}_{2}$ for 1 day. The $\mathrm{V}_{\text {cyt }}$ of fruit transferred to air for 1 day following low- $\mathrm{O}_{2}$ storage was not significantly different from the $\mathrm{V}_{\text {cyt }}$ of fruit stored in $1.5 \% \mathrm{O}_{2}$ for 1 day. There were no differences in the capacity of $\mathrm{V}_{\text {cyt }}$ and $\mathrm{V}_{\text {at }}$ between fruit stored in air for 1 or 2 days. The ratio of $\mathrm{V}_{\text {all }} / \mathrm{V}_{\text {cyt }}$ of fruit stored in $1.5 \% \mathrm{O}_{2}$ for 1 day was not significantly different from that of fruit stored in air (Table 5). Twenty four hours after transferring fruit from low $\mathrm{O}_{2}$ to air, the $\mathrm{V}_{\text {al }} / \mathrm{V}_{\text {cyt }}$ ratio recovered by about $15 \%$ and was significantly $(P \leq 0.01)$ higher from that of the air-stored fruit. The level of residual respiration $\left(\mathrm{V}_{\mathrm{res}}\right)$ in the purified mitochondria was negligible for all treatments (Table 5).

Further experiments were conducted to examine the influence of extended low- $\mathrm{O}_{2}$ storage on bell pepper mitochondrial oxidative components. The $\mathrm{V}_{\mathrm{T}}$ of mitochondria isolated from fruit stored in $1.5 \% \mathrm{O}_{2}$ for 5 days was significantly $(P \leq 0.01)$ lower $(43 \%)$ than that of mitochondrial isolates from air-stored fruit (Table 6). Twenty four hours after transfer of fruit from low $\mathrm{O}_{2}$ to air, the $\mathrm{V}_{\mathrm{T}}$ attained values similar to those of the air-stored fruit. The $\mathrm{V}_{\mathrm{T}} \mathrm{w}$ as not significantly different between fruit stored in air for 5 or 6 days. The capacities of $\mathrm{V}_{\text {cyt }}$ and $\mathrm{V}_{\text {att }}$ were suppressed by about $35 \%$ and $60 \%$, respectively, after storage of fruit for 5 days in $1.5 \% \mathrm{O}_{2}$, and were significantly $(P \leq 0.01)$ lower than the values for air-stored fruit (Table 6). $\mathrm{V}_{\mathrm{cyt}}$ and $\mathrm{V}_{\mathrm{at}}$ increased, by about $35 \%$ and $65 \%$, respectively, 1 day after transferring fruit from low $\mathrm{O}_{2}$ to air. Although the $\mathrm{V}_{\mathrm{cyt}}$ recovered after transferring fruit to air, it remained significantly $(P \leq 0.01)$ lower than the values obtained for fruit stored continuously in air. The $\mathrm{V}_{\mathrm{al}} / \mathrm{V}_{\mathrm{cy}}$ ratio was reduced after storing fruit for 5 days in $1.5 \% \mathrm{O}_{2}$, but recovered by about $47 \% 1$ day after transferring fruit from low $\mathrm{O}_{2}$ to air. The contribution of $\mathrm{V}_{\text {res }}$ to the total respiratory activity of mitochondria was negligible (Table 6).

In our determinations of the proportional capacities of the two electron-transport components in bell pepper mitochondria, $\mathrm{V}_{\text {alt }}$ was consistently higher than $\mathrm{V}_{\text {cyt }}$. These data represent the $\mathrm{V}_{\text {alt }}$ and $\mathrm{V}_{\mathrm{cyy}}$ capacities and do not necessarily reflect the extent of engagement in vivo. It is noteworthy, however, that mitochondria from mature-green tomatoes and cauliflower florets, neither of which exhibited a significant PRS in response to hypoxia, exhibited the more typical pattern of $\mathrm{V}_{\mathrm{cyt}}>\mathrm{V}_{\text {alt }}$ (unpublished data).

\section{Discussion}

Previous studies (Rahman et al., 1993) demonstrated that bell peppers stored in low- $\mathrm{O}_{2}$ atmospheres for 1 to 3 days exhibited suppressed total organ $\mathrm{O}_{2}$ consumption and $\mathrm{CO}_{2}$ evolution upon transfer to normal atmospheres. This postharvest respiratory sup- 
Table 5. Contribution of the alternative $\left(\mathrm{V}_{\text {att }}\right)$ and cytochrome $\left(\mathrm{V}_{\text {cy }}\right)$ pathways and residual respiration $\left(\mathrm{V}_{\text {,,) }}\right.$ to the total respiratory activity $\left(\mathrm{V}_{\mathrm{T}}\right)$ in mitochondria from fruit stored in $1.5 \% \mathrm{O}_{2}$ for 1 day and 1 day after transfer from low 0 , to air.

\begin{tabular}{|c|c|c|c|c|c|}
\hline \multirow[b]{2}{*}{ Treatment } & \multicolumn{5}{|c|}{$\begin{array}{c}\text { Oxygen consumption rate } \mathrm{z}^{\mathrm{z}} \\
\text { (nmol } \mathrm{O}_{2} / \mathrm{mg} \text { mitochondrial protein per } \mathrm{min} \text { ) }\end{array}$} \\
\hline & $\mathrm{V}_{\mathrm{T}}$ & $\mathrm{V}_{\mathrm{cyt}}$ & $\mathrm{V}_{\text {alt }}$ & $\mathrm{V}_{\text {res }}$ & $\mathrm{V}_{\mathrm{alt}} / \mathrm{V}_{\mathrm{cyt}}$ \\
\hline $1 \mathrm{Day} / 1.5 \% \mathrm{O}_{2}$ & $194.6 \mathrm{ab}^{2}$ & $52.3 \mathrm{a}$ & $106.1 \mathrm{~b}$ & $0.13 \mathrm{a}$ & $2.03 \mathrm{~b}$ \\
\hline 1 Day/air & $189.6 \mathrm{bc}$ & $44.2 \mathrm{~b}$ & $87.2 \mathrm{c}$ & $0.17 \mathrm{a}$ & $1.98 \mathrm{~b}$ \\
\hline $1 \mathrm{Day} / 1.5 \% \mathrm{O}_{2}+1$ day/air & $198.3 \mathrm{a}$ & $54.3 \mathrm{a}$ & $127.2 \mathrm{a}$ & $0.13 \mathrm{a}$ & $2.35 \mathrm{a}$ \\
\hline 2 Days/air & $186.5 \mathrm{c}$ & $44.1 \mathrm{~b}$ & $87.3 \mathrm{c}$ & $0.00 \mathrm{a}$ & $1.98 \mathrm{~b}$ \\
\hline
\end{tabular}

${ }^{\mathrm{z}}$ Data are means of three replications. Means followed by the same letter within a column are not significantly different at 0.01 level by DMRT.

Table 6. Contribution of the alternative $\left(\mathrm{V}_{\text {att }}\right)$ and cytochrome $\left(\mathrm{V}_{\mathrm{cy}}\right)$ pathways and residual respiration $(\mathrm{V}$, ,) to the total respiratory activity $\left(\mathrm{V}_{\mathrm{T}}\right)$ in mitochondria from fruit stored in $1.5 \% \mathrm{O}_{2}$ for 5 days and 1 day after transfer from low 0 , to air.

\begin{tabular}{|c|c|c|c|c|c|}
\hline \multirow[b]{2}{*}{ Treatment } & \multicolumn{5}{|c|}{$\begin{array}{c}\text { Oxygen consumption rate } \\
\text { (nmol } \mathrm{O}_{2} / \mathrm{mg} \text { mitochondrial protein per min) }\end{array}$} \\
\hline & $\mathrm{V}_{\mathrm{T}}$ & $\mathrm{V}_{\mathrm{cyt}}$ & $\mathrm{V}_{\mathrm{alt}}$ & $\mathrm{V}_{\mathrm{res}}$ & $\mathrm{V}_{\mathrm{all}} / \mathrm{V}_{\mathrm{cyt}}$ \\
\hline 5 Days $/ 1.5 \% \mathrm{O}_{2}$ & $62.2 \mathbf{b}^{\mathrm{x}}$ & $23.1 \mathrm{c}$ & $22.9 \mathrm{~b}$ & $1.0 \mathrm{a}$ & $0.99 \mathrm{~d}$ \\
\hline 5 Days/air & $109.2 \mathrm{a}$ & $35.8 \mathrm{~b}$ & $60.2 \mathrm{a}$ & $0.6 \mathrm{~b}$ & $1.68 \mathrm{~b}$ \\
\hline 5 Days $/ 1.5 \% \mathrm{O}_{2}+1$ day/air & $107.2 \mathrm{a}$ & $35.7 \mathrm{~b}$ & $65.0 \mathrm{a}$ & $0.7 \mathrm{~b}$ & $1.82 \mathrm{a}$ \\
\hline 6 Days/air & $108.7 \mathrm{a}$ & $48.8 \mathrm{a}$ & $62.6 \mathrm{a}$ & $0.9 \mathrm{a}$ & $1.28 \mathrm{c}$ \\
\hline
\end{tabular}

${ }^{\mathrm{z}}$ Data are means of three replications. Means followed by the same letter within a column are not significantly different at 0.01 level by DMRT.

pression (PRS) was not reflected in the total oxidative capacity of isolated mitochondria (Rahman et al., 1993). This observation provides evidence that the PRS exhibited by intact bell peppers was due to factors such as impairment in general carbon flux or inhibition of nonmitochondrial oxidases. It is also possible that direct effects on mitochondria are rapidly rectified after transferring fruit from low $\mathrm{O}_{2}$ to air or do not persist after isolating and incubating mitochondria in the substrate-rich environment under which oxidative capacity is determined. In further attempts to determine the influence of low- $\mathrm{O}_{2}$ storage on mitochondrial reactions, bell peppers were subjected to longer exposures (5 days) to $1.5 \% \mathrm{O}_{2}$.

The data confirmed our previous observations (Rahman et al., 1993) that exposing bell peppers to $1.5 \% \mathrm{O}_{2}$ for 1 day exerted no apparent effect on the total capacity of mitochondria to use succinate. Additionally evident in the present study is that the RC and $\mathrm{ADP} / \mathrm{O}$ ratios were not affected by storing fruit for 1 day in $1.5 \% \mathrm{O}_{2}$.

Storing bell pepper fruit in $1.5 \% \mathrm{O}_{2}$ for 5 days suppressed $\mathrm{CO}_{2}$ production for at least $55 \mathrm{~h}$ following transfer to air. This compares to the 24-h PRS observed for fruit stored for 1 day in $1.5 \% \mathrm{O}_{2}$ (Rahman et al., 1993) and demonstrates that the PRS is prolonged following extended exposure to low $\mathrm{O}_{2}$. In contrast to the effect of $1.5 \% \mathrm{O}_{2}$ for 1 day, 5 days storage in $1.5 \% \mathrm{O}_{2}$ resulted in a marked reduction in the total oxidative capacity of isolated mitochondria. The reduction in $\mathrm{V}_{\mathrm{T}}$ was temporary and mitochondria attained normal total oxidative capacity within 1 day of transferring fruit from low $\mathrm{O}_{2}$ to air. The recovery in total oxidative capacity was not immediate, however, as $\mathrm{V}_{\mathrm{T}}$ measured $10 \mathrm{~h}$ after transferring fruit from low $\mathrm{O}_{2}$ to air was still lower than that of mitochondria from air-stored fruit. This time period $(10 \mathrm{~h})$ is in excess of the period required (about $2 \mathrm{~h}$ ) for equilibration of internal fruit atmosphere with air (i.e., $21 \% \mathrm{O}_{2}$ ) on removing fruit from low $\mathrm{O}_{2}$ and is indicative of a direct effect of low $\mathrm{O}_{2}$ on mitochondrial function. Anaerobic injury seems unlikely in view of the absence of detectable levels of ethanol in low $\mathrm{O}_{2}$-stored peppers (Rahman et al.,
1993). It is possible that the temporary suppression in total mitochondrial oxidative capacity following low $\mathrm{O}_{2}$ storage reflects an impairment in the capacity of mitochondna to mobilize key substrates. Kays (1991) noted that changes in the internal environment brought about by controlled-atmosphere storage can result in significant metabolic shifts in reactions at which regulatory pathways are controlled. McGlasson and Wills (1972) indicated that low $\mathrm{O}_{2}\left(3 \% \mathrm{O}_{2}, 97 \% \mathrm{~N}_{2}\right)$ caused significant increases in pyruvate, oxaloacetate and $\alpha$ - ketoglutarate levels in banana fruit stored for 1 to 4 days at 20C. These authors suggested that low $\mathrm{O}_{2}$ limited the operation of the citric acid cycle between pyruvate and citrate, and between $\alpha$ - ketoglutarate and succinate.

A reduction in the total mitochondrial oxidative capacity $\left(\mathrm{V}_{\mathrm{T}}\right)$ after exposing bell peppers to $1.5 \% \quad \mathrm{O}_{2}$ for 5 days was accompanied by a temporary reduction in the $\mathrm{RC}$ values. Unlike total oxidative capacity; however, RC values recovered to control levels within 10 $\mathrm{h}$ following transferring fruit to air.

A reduction in $\mathrm{V}_{\mathrm{T}}$ after storing bell peppers in $1.5 \% \mathrm{O}_{2}$ for 5 days was accompanied by a suppression in the activity of $\mathrm{V}_{\mathrm{cyt}}$ and $\mathrm{V}_{\text {alt }}$. The activity of both respiratory pathways recovered within 1 day after transferring fruit to air, however, the magnitude of recovery was greater for $\mathrm{V}_{\text {at }}$ than $\mathrm{V}_{\text {cyy }}$. The increased capacity of $\mathrm{V}_{\text {att }} 1$ day after transferring bell peppers from low $\mathrm{O}_{2}$ to air may be explained on the basis that energy and ATP are not limiting and $\mathrm{V}_{\mathrm{cyt}}$ is saturated with electrons (Lambers, 1980; Palmer, 1976). Under these conditions, the ubiquinone pool is highly reduced, causing electron flow to shift from $\mathrm{V}_{\text {cyt }}$ to $\mathrm{V}_{\text {alt }}$ (Weger et al., 1990; Lambers, 1980). This shift to the nonphosphorylative $V_{\text {at }}$ allows the citric acid cycle to remain operational with minimal ATP production (Rasmusson et al., 1990) and enables metabolism to continue when cellular energy charge is high (Lambers, 1982). Conditions of high ATP and NADH/NAD ${ }^{+}$ratios can inhibit the activity of pyruvate dehydrogenase, reducing the conversion of pyruvate to acetyl CoA (Kays, 1991). Kiener and Bramlage (1981) reported that the $\mathrm{V}_{\text {att }}$ of cucumber hypocotyls became engaged during the postchilling respiratory burst, and also in postchilled tomatoes (De 
Virville et al., 1987). Similarly, Inaba and Chachin (1989) observed an increase in $\mathrm{V}_{\text {alt }}$ in tomatoes following exposure to 30 or $35 \mathrm{C}$.

This study indicates that the PRS after exposing bell peppers to low- $\mathrm{O}_{2}$ atmosphere can be explained, in part, by reduced oxidative capacity of mitochondria. Although the present study addressed suppressed total organ $\mathrm{CO}_{2}$ exchange and mitochondrial oxidative capacity during the period following exposure to low $\mathrm{O}_{2}$, these effects are likely operational during the low- $\mathrm{O}_{2}$ exposure and may help explain the effectiveness of controlled atmospheres in extending the postharvest longevity of harvested organs. The efficacy of controlled-atmosphere storage is frequently explained on the basis of specific effects of altered $\mathrm{O}_{2}$ or $\mathrm{CO}_{2}$ levels on the synthesis and action of ethylene (Kubo et al., 1990). Ethylene has been shown to induce or increase the capacity of $\mathrm{V}_{\text {alt }}$ in potato tuber tissue (Gude and van der Plas, 1985), pea seedlings (Duncan and Spencer, 1987), and iris bulbs (Marissen et al., 1986). As bell peppers produce minimal quantities of ethylene during postharvest storage and show no change in ethylene production in response to low-O, storage (Rahman et al., 1993), peppers may be useful for investigating the biochemistry of controlled atmospheres independent of the influence of ethylene.

\section{Literature Cited}

De Virville, J.D., P. Diolez, F. Moreau, C. Dessaux, and P. Morcellin. 1987. Oxidative and phosphorylating activities of mitochondria isolated from tomato fruit during the post-chilling burst of respiration. J. Plant Physiol. 129:341-349.

Duncan, I. and M. Spencer. 1987. Changes in respiration of mitochondria isolated from cotyledons of ethylene-treated pea seedlings. Planta 170:44-48.

Estabrook, R.W. 1967. Mitochondrial respiratory control and the polarographic measurement of ADP : O ratios. Meth. Enzymol. 10:41-47.

Goodwin, T.W. and E.I. Mercer. 1988. Introduction to plant biochemistry. Pergamon Press, New York. p. 162-204.

Gude, H. and L.H.W. Van der Plas. 1985. Endogenous ethylene formation and the development of the alternative pathway in potato tuber discs. Physiol. Plant. 65:57-62.

Inaba, M. and K. Chachin. 1989. High temperature stress and mitochondrial activity of harvested mature-green tomatoes. J. Amer. Soc. Hort.
Sci. 114:809-814.

Kader, A.A. 1986. Biochemical and biophysical basis for effects of controlled and modified atmospheres on fruits and vegetables. Food Technol. 40:99-104.

Kays, S.J. 1991. Postharvest physiology of perishable plant products. Van Nostrand Reinhold, New York. p. 358-361.

Kiener, CM. and W.J. Bramlage. 1981. Temperature effects on the activity of the alternative respiratory pathway in chill-sensitive Cucumis sativus. Plant Physiol. 68:1474-1478.

Kubo, Y., A. Inaba, and R. Nakamura. 1990. Respiration and $\mathrm{C}_{2} \mathrm{H}_{4}$ production in various harvested crops held in $\mathrm{CO}_{2}$-enriched atmospheres. J. Amer. Soc. Hort. Sci. 115.:975-978.

Lambers, H. 1980. The physiological significance of cyanide-resistant respiration in higher plants. Plant Cell Environ. 3:293-302.

Lambers, H. 1982. Cyanide-resistant respiration: A non phosphorylation electron transport pathway acting as an energy overflow. Plant Physiol. 55:478-485.

Marissen, N., L.H.W. Van der Plas, and J.G. Duys. 1986. Influence of temperature, ethylene and cyanide on the occurrence of alternative respiration in mitochondria from iris bulbs. Plant Sci. 45: 19-25.

McGlasson, W.B. and R.B.H. Wills. 1972. Effects of oxygen and carbon dioxide on respiration, storage life, and organic acids of green bananas. Austral. J. Biol. Sci. 25:35-42.

Mikitzel, L. and N.R. Knowles. 1990: Changes in respiratory metabolism during sprouting of aged seed-potato tubers. Can. J. Bot. 68:1619-1626.

Ordentlich, A., R.A. Linzer, and I. Raskin. 1991. Alternative respiration and heat evolution in plants. Plant Physiol. 97:1545-1560.

Palmer, J.M. 1976. The organization and regulation of electron transport in plant mitochondria. Annu. Rev. Plant Physiol. 27:133-157.

Rahman, A.S.A., D.J. Huber, and J.K. Brecht. 1993. Respiratory activity and mitochondrial oxidative capacity of bell pepper fruit under lowoxygen atmosphere. J. Amer. Soc. Hort. Sci. 118:470-475.

Rasmusson, A.G., I.M. Moller, and J.M. Palmer. 1990. Component of the alternative oxidase localized to the matrix surface of the inner membrane of plant mitochondria. FEBS Lett. 259:311-314.

Smith P.K., R.I. Krohn, G.T. Hermanson, A.K. Mallia, F.H. Gartner, M.D. Provenzano, E.K. Fujimoto, N.M. Geoke, B.J. Olson, and D.C. Klenk. 1985. Measurements of protein using bicinchoninic acid. Anal. Biochem. 150:76-85.

Weger, H.G., R.D. Guy, and D.H. Turpin. 1990. Cytochrome and alternative pathway respiration in green algae. Plant Physiol. 93:356-360. 